\title{
Sciendo
}

DOI: $10.1515 /$ sspjce-2020-0026

\section{Structural diagnostics and structural analysis of precast concrete building}

\author{
Ivo Demjan, Michal Tomko, Róbert Šoltýs \\ Technical University of Košice, Slovakia \\ Civil Engineering Faculty, Institute of Structural Engineering \\ e-mail: ivo.demjan@tuke.sk,michal.tomko@tuke.sk, robert.soltys@tuke.sk
}

\begin{abstract}
The aim of this paper was to estimate further service possibilities of precast concrete structure. It was necessary to remain basic reliability conditions for actual service conditions. To reach this goal a complex experimental diagnostics and structural analysis was applied. On the basis of these methods construction arrangements recommendations were defined.
\end{abstract}

Key words: structural diagnostics, structural analysis, numerical modelling

\section{Introduction}

A structural diagnostics was realised to determine the size and development of visible cracks of structural system of a building, i.e. time-dependent monitoring of the development of cracks in the load-bearing reinforced concrete structure and brick masonry, experimental determination of in situ concrete strength of selected reinforced concrete elements, deformation of selected load-bearing concrete structures and determination of floor composition and geological exploration of natural bedrock close to the observed object.

\section{Characteristics of the object}

The building is composed of three load bearing systems:

1) The middle part, Fig. 1 b):

From a structural point of view, this is a four-storey precast reinforced skeleton revised by Priemstav (MSRP) with a $6 \times 4.8 \mathrm{~m}$ and $6 \times 2.4 \mathrm{~m}$ modular system. Ceiling panels are of type PZD 5/475. The reinforcing system consists of four reinforced concrete, or brick walls. The building is fixed to foundation piles with a diameter of $430 \mathrm{~mm}$ and a depth of 6.8 meters. 
2) The front, Fig. 1 a):

Vertical support structures consist of brick masonry supported by reinforced concrete beams fixed to foundation piles with a depth of 5.5 meters. The horizontal load-bearing structure consists of PPD 918/312 prestressed panels. The cross-section shows a retreating cascade design. The longitudinal panels with a length of $9 \mathrm{~m}$ are supported by the peripheral wall between the two floors.

3) Back part, Fig. $1 \mathrm{c})$ :

From a structural point of view, this is a two-storey precast reinforced skeleton revised by Priemstav (MSRP) with a of $6 \times 6 \mathrm{~m}, 6 \times 2.4 \mathrm{~m}$ and $6 \times 12 \mathrm{~m}$ modular system. Ceiling panels are of type PZD 5/475, PPD 668/312, and others [1]. Vertical walls are brick masonry based on foundation strips. The building is based on a foundation of precast reinforced concrete footings. Beneath the whole object lies a complicated and dense network of channels for utility services.

a)

b)

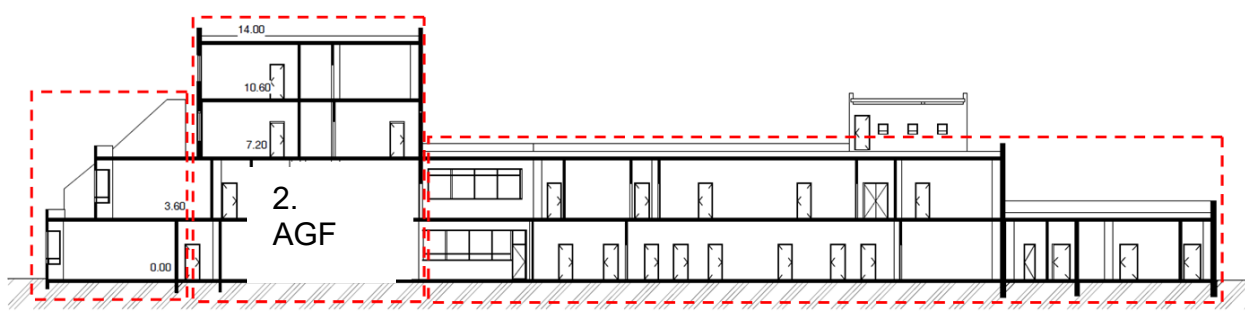

Figure 1: Longitudinal section

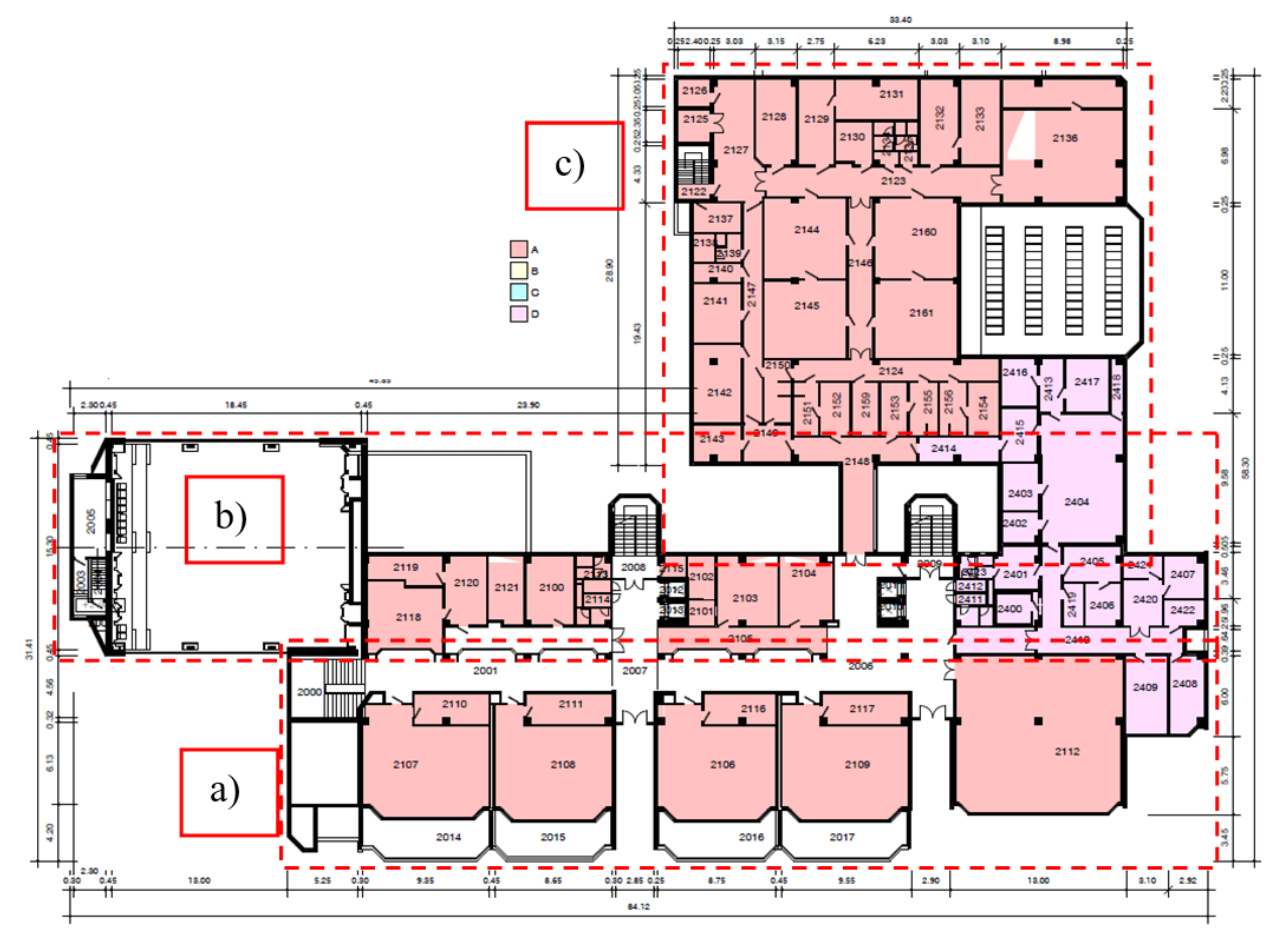

Figure 2: Floorplan of $2^{\text {nd }}$ floor 


\section{Current condition}

The following defects were found in the building structure:

- two rooms (classroom - 1, classroom - 2) precast prestressed concrete ceiling panels (PPD 918/312) show excessive deflections and are supported by steel struts;

- deformed (wavy) floors are observed in several rooms of the building;

- large cracks in the walls, also deformed door frames in one room on the first floor and damaged lining around windows;

- in one room (classroom - 2) a part or the tension reinforcement in part of the precast prestressed concrete ceiling panel is probably damaged;

- $\quad$ rising damp is clearly visible in ceilings and walls due to infiltration from atmospheric precipitation.

a)

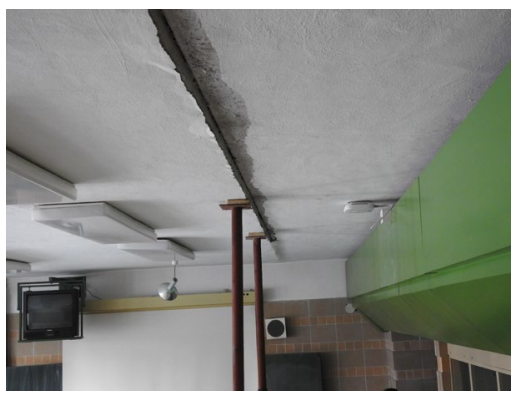

b)

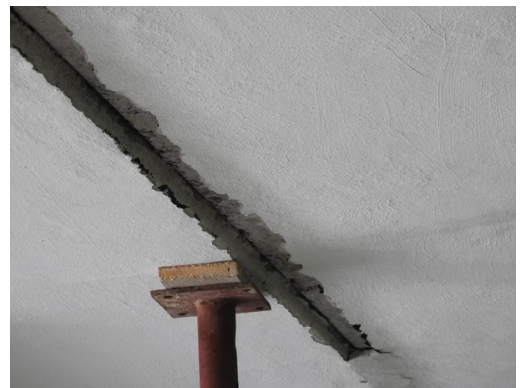

c)

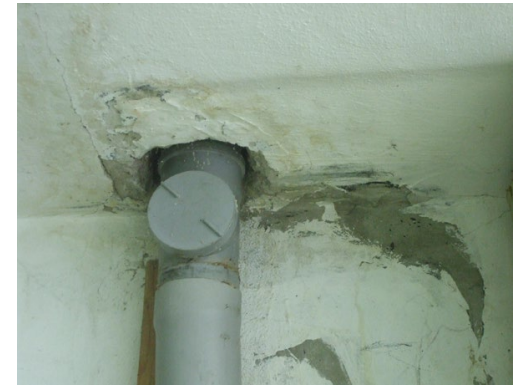

Figure 3: Photo documentation of the current state of the structure;

a) Supports of the deformed panel PPD 918/312

b) Detail of mutual difference in the decline of the two adjacent panels

c) Additionally created downpipes, which damaged the prestressed edge cables in panel PPD 918/312 in room 2109

\section{$4 \quad$ In-situ structural diagnostics of precast concrete building skeletons}

Measuring the strength of concrete was carried out on the supporting horizontal panels PPD 918/312 and reinforced peripheral crown using a Schmidt rebound hammer.

\subsection{Compressive strength of precast concrete ceiling panels}

PPD 918/312 panels in the ceiling structure used for transmitting the vertical load interact mutually through joints made of liquid steel sealants and reinforcement. Malfunctions in the joint of the panel have demonstrated a significant burden of one of the panels and may deform when transferring vertical load.

The experimental findings of in-situ concrete strength of precast prestressed concrete ceiling panels type 918/312 PPD were carried out in room 2109 (classroom - 1), Fig. 4, and room 2106 (classroom - 2), Fig. 5. 
Experimental measurements of in-situ strength of the concrete ceiling of unsupported PZD 5/475 reinforced concrete panels were conducted in room 2103, Fig. 6.

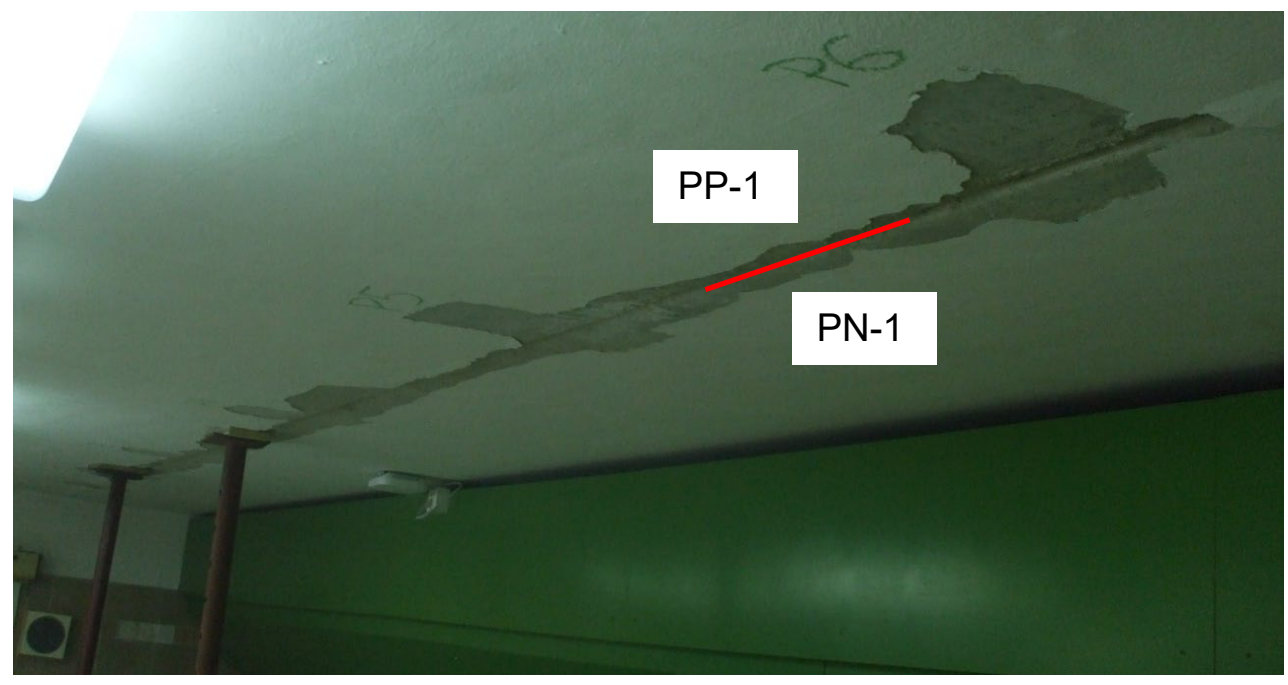

Figure 4: View of the reinforced concrete ceiling panels in room 2109 PP-1 ... ceiling panel (PPD 918/312) supported by steel struts PN-1 ... ceiling panel (PPD 918/312) not supported by steel struts

Table 1: Measured values of Schmidt recoil hammer N in room 2109 For: PP-1 ... ceiling panel (PPD 918/312) supported by steel struts PN-1 ... ceiling panel (PPD 918/312) not supported with steel struts

\begin{tabular}{|c|c|c|c|c|c|c|}
\hline Location & Schmidt rebound & \multirow[t]{2}{*}{ Mean } & $R_{b e}$ & Schmidt rebound & \multirow[t]{2}{*}{ Mean } & $R_{b e}$ \\
\hline Position & PP-1 & & $\begin{array}{c}\mathrm{MPa} \\
]\end{array}$ & $\mathrm{PN}-1$ & & {$[\mathrm{MPa}$} \\
\hline P1 & \multirow{2}{*}{$\begin{array}{c}57,58,58,58, \\
57, \\
58,58,56,56,56\end{array}$} & \multirow[t]{2}{*}{57.2} & \multirow[t]{2}{*}{64} & \multirow[t]{2}{*}{$57,58,60,58,59$} & \multirow[t]{2}{*}{58.4} & \multirow[t]{2}{*}{66} \\
\hline Vertical & & & & & & \\
\hline $\mathrm{P} 2$ & \multirow{2}{*}{$\begin{array}{c}58,58,58,59 \\
58, \\
57,56,58,59,57\end{array}$} & \multirow[t]{2}{*}{57.8} & \multirow[t]{2}{*}{65} & \multirow[t]{2}{*}{$56,58,58,56,58$} & \multirow[t]{2}{*}{57.2} & \multirow[t]{2}{*}{64} \\
\hline Vertical & & & & & & \\
\hline P3 & \multirow{2}{*}{$\begin{array}{c}56,58,56,58, \\
58, \\
56,58,58,56,58\end{array}$} & \multirow[t]{2}{*}{57.2} & \multirow[t]{2}{*}{64} & \multirow[t]{2}{*}{$59,61,57,57,59$} & \multirow[t]{2}{*}{58.6} & \multirow[t]{2}{*}{66} \\
\hline Vertical & & & & & & \\
\hline $\mathrm{P} 4$ & \multirow{2}{*}{$\begin{array}{c}58,56,56,58, \\
56, \\
56,55,58,58,56\end{array}$} & \multirow[t]{2}{*}{56.7} & \multirow[t]{2}{*}{63} & \multirow[t]{2}{*}{$57,57,57,56,59$} & \multirow[t]{2}{*}{57.2} & \multirow[t]{2}{*}{64} \\
\hline Vertical & & & & & & \\
\hline P5 & \multirow{2}{*}{$\begin{array}{c}56,58,54,58, \\
56, \\
55,59,58,57,58\end{array}$} & \multirow[t]{2}{*}{56.9} & \multirow[t]{2}{*}{63} & \multirow[t]{2}{*}{$55,55,54,58,56$} & \multirow[t]{2}{*}{55.6} & \multirow[t]{2}{*}{61} \\
\hline Vertical & & & & & & \\
\hline $\mathrm{P} 6$ & \multirow{2}{*}{$\begin{array}{c}57,57,58,58, \\
58, \\
54,56,58,54,53\end{array}$} & \multirow[t]{2}{*}{56.3} & \multirow[t]{2}{*}{62} & \multirow[t]{2}{*}{$57,54,58,53,56$} & \multirow[t]{2}{*}{55.6} & \multirow[t]{2}{*}{61} \\
\hline Vertical & & & & & & \\
\hline
\end{tabular}




$$
\begin{aligned}
\text { Mean } R_{b e} & =63.5 \mathrm{MPa} \\
f_{c, c u b e} & =53.9 \mathrm{MPa}
\end{aligned}
$$

$$
\begin{aligned}
\text { Mean } R_{b e} & =63.7 \mathrm{MPa} \\
f_{c, c u b e} & =54.2 \mathrm{MPa}
\end{aligned}
$$

Compressive strength for precast prestressed PPD 918/312 concrete ceiling panel complies with class C 45/55 concrete.

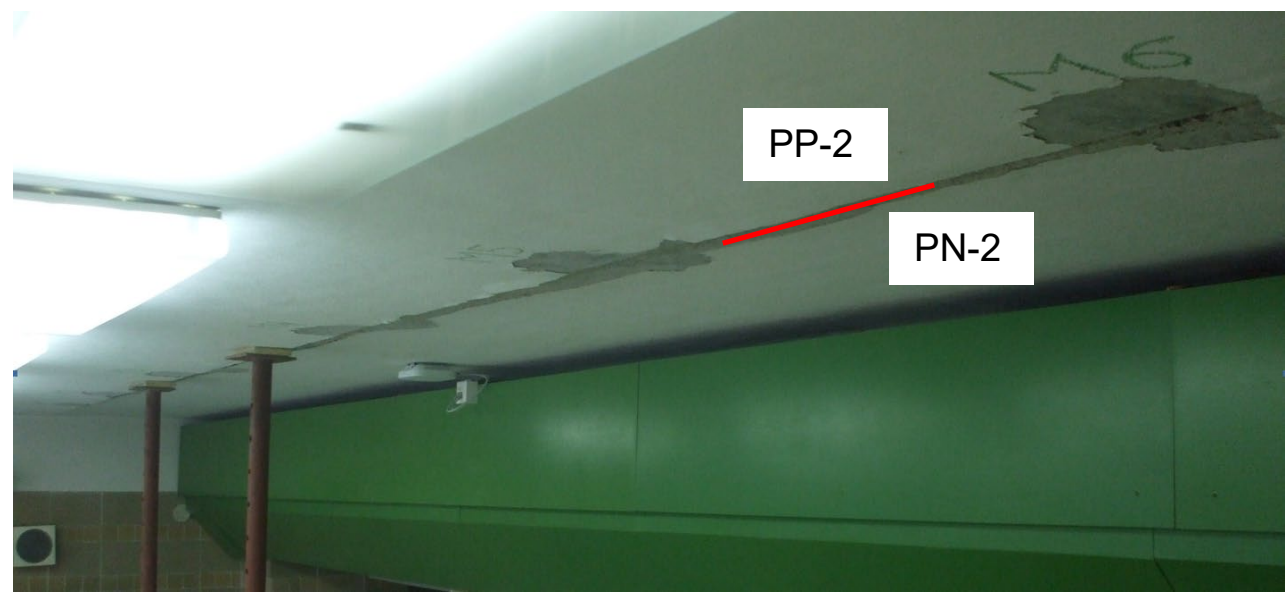

Figure 5: View of the reinforced concrete ceiling panels in room 2106 PP-2 ... ceiling panel (PPD 918/312) supported by steel struts PN-2 ... ceiling panel (PPD 918/312) not supported by steel struts

\begin{tabular}{|c|c|c|c|c|c|c|}
\hline Location & Schmidt rebound & \multirow[t]{2}{*}{ Mean } & $R_{b e}$ & Schmidt rebound & \multirow[t]{2}{*}{ Mean } & $R_{b e}$ \\
\hline Position & PP-2 & & $\begin{array}{c}{[\mathrm{MPa}} \\
]\end{array}$ & $\mathrm{PN}-2$ & & $\begin{array}{c}{[\mathrm{MPa}} \\
]\end{array}$ \\
\hline M1 & \multirow{2}{*}{$\begin{array}{c}54,55,57,54 \\
56, \\
58,57,55,57,58\end{array}$} & \multirow[t]{2}{*}{56.1} & \multirow[t]{2}{*}{62} & \multirow[t]{2}{*}{$53,54,55,54,53$} & \multirow[t]{2}{*}{53.8} & \multirow[t]{2}{*}{59} \\
\hline Vertical & & & & & & \\
\hline M2 & \multirow{2}{*}{$\begin{array}{c}55,56,56,54 \\
53, \\
57,57,57,58,57\end{array}$} & \multirow[t]{2}{*}{56.0} & \multirow[t]{2}{*}{62} & \multirow[t]{2}{*}{$60,57,53,54,58$} & \multirow[t]{2}{*}{56.4} & \multirow[t]{2}{*}{62} \\
\hline Vertical & & & & & & \\
\hline M3 & \multirow{2}{*}{$\begin{array}{c}56,57,58,55, \\
58, \\
56,54,56,56,57\end{array}$} & \multirow[t]{2}{*}{56.3} & \multirow[t]{2}{*}{62} & \multirow[t]{2}{*}{$54,56,55,52,52$} & \multirow[t]{2}{*}{53.8} & \multirow[t]{2}{*}{59} \\
\hline Vertical & & & & & & \\
\hline M4 & \multirow{2}{*}{$\begin{array}{c}57,55,57,56, \\
57, \\
56,55,58,55,58\end{array}$} & \multirow[t]{2}{*}{56.4} & \multirow[t]{2}{*}{62} & \multirow[t]{2}{*}{$55,55,56,55,57$} & \multirow[t]{2}{*}{55.6} & \multirow[t]{2}{*}{61} \\
\hline Vertical & & & & & & \\
\hline M5 & \multirow{2}{*}{$\begin{array}{c}58,58,56,57, \\
56, \\
57,58,57,60,56\end{array}$} & \multirow[t]{2}{*}{57.3} & \multirow[t]{2}{*}{64} & \multirow[t]{2}{*}{$56,55,56,54,51$} & \multirow[t]{2}{*}{54.4} & \multirow[t]{2}{*}{60} \\
\hline Vertical & & & & & & \\
\hline M6 & $58,56,58,57$ & 57.5 & 64 & $56,55,53,54,54$ & 54.4 & 60 \\
\hline
\end{tabular}

Table 2: Measured values of Schmidt recoil hammer N in room 2106 For: PP-2 ... ceiling panel (PPD 918/312) supported by steel struts PN-2 ... ceiling panel (PPD 918/312) not supported by steel struts 


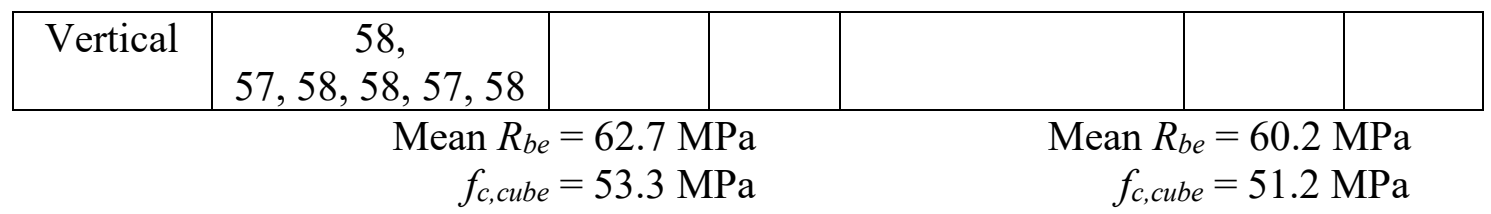

Compressive strength for precast prestressed concrete ceiling panel PPD 918/312 complies with class $\mathrm{C} 45 / 55$ concrete.

Room 2103 is an office and is located on the first floor in the front segment of the building structure.

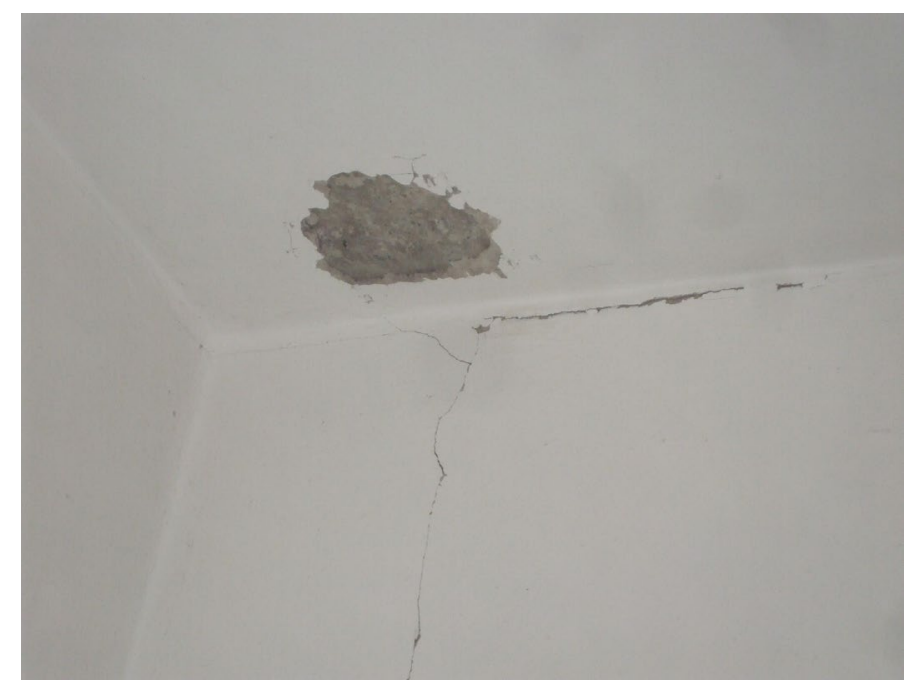

Figure 6: View of the precast concrete ceiling panel (PZD 5/475) in room 2103

Table 3: Measured values of Schmidt recoil hammer N in room 2103 for panels PZD 5/475

\begin{tabular}{|c|c|c|c|}
\hline Location & Schmidt rebound & Mean & $R_{b e}$ \\
\cline { 1 - 2 } Position & & & $\begin{array}{c}\mathrm{MPa} \\
]\end{array}$ \\
\hline S1 & $46,45,49,46$, & 46.6 & 42 \\
& 42, & & \\
\hline Vertical & $48,47,46,48,49$ & $\mathrm{MPa}$ \\
& \multicolumn{3}{|c|}{ Mean $R_{b e}=42.0 \mathrm{MP}$} \\
$f_{c, \text { cube }}=35.7 \mathrm{MPa}$
\end{tabular}

Compressive strength of unsupported precast concrete ceiling panel PZD 5/475 complies with class C 30/37.

\subsection{Compressive strength of precast concrete bond beams}

The experimental findings of in-situ compressive strength of the peripheral concrete bond beam were carried out in room 2109 (classroom - 1) and in room 2106 (classroom - 2), Fig. 7. 
Bond beam (V1)
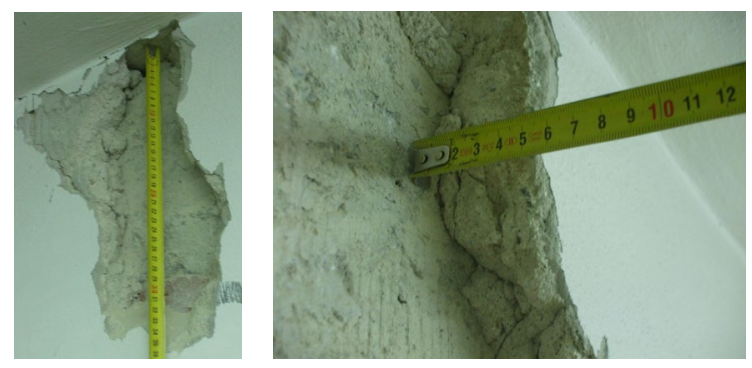

Bond beam (V2)
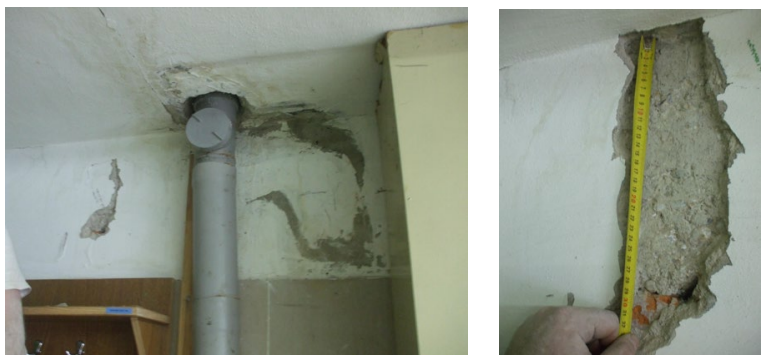

Figure 7: View of the reinforced concrete bond beam (V1) and (V2) height of bond beam (V1) is $28.5 \mathrm{~cm}$, plaster thickness 5 to $5.5 \mathrm{~cm}$ height of bond beam (V2) is $29 \mathrm{~cm}$, plaster thickness $2 \mathrm{~cm}$

Table 4: Measured values of Schmidt recoil hammer N in room 2109 (classroom - 1) of precast concrete bond beam V1

\begin{tabular}{|c|c|c|c|}
\hline Location & \multirow[t]{2}{*}{ Schmidt rebound } & \multirow[t]{2}{*}{ Mean } & $R_{b e}$ \\
\hline Position & & & $\begin{array}{c}{[\mathrm{MPa}} \\
]\end{array}$ \\
\hline V1 & \multirow{2}{*}{$\begin{array}{c}34,39,38,38, \\
34, \\
34,37,36,38,38\end{array}$} & \multirow[t]{2}{*}{36.6} & \multirow[t]{2}{*}{34} \\
\hline Horizontal & & & \\
\hline $\mathrm{V} 2$ & \multirow{2}{*}{$\begin{array}{c}35,37,38,36, \\
37, \\
36,37,36,37,38\end{array}$} & \multirow[t]{2}{*}{36.7} & \multirow[t]{2}{*}{34} \\
\hline Horizontal & & & \\
\hline
\end{tabular}

Compressive strength of the reinforced concrete ceiling panel complies with class C 25/30.

\subsection{Composition and thickness of floors}

The thickness and composition of floor on precast prestressed concrete ceiling panel PPD 918/312 and on unsupported precast concrete ceiling panel PZD 5/475 was experimentally determined in-situ via probes.

The thickness of the floor on the ceiling panel consists of levelling concrete and screed with a total thickness of about $8 \mathrm{~cm}$. 

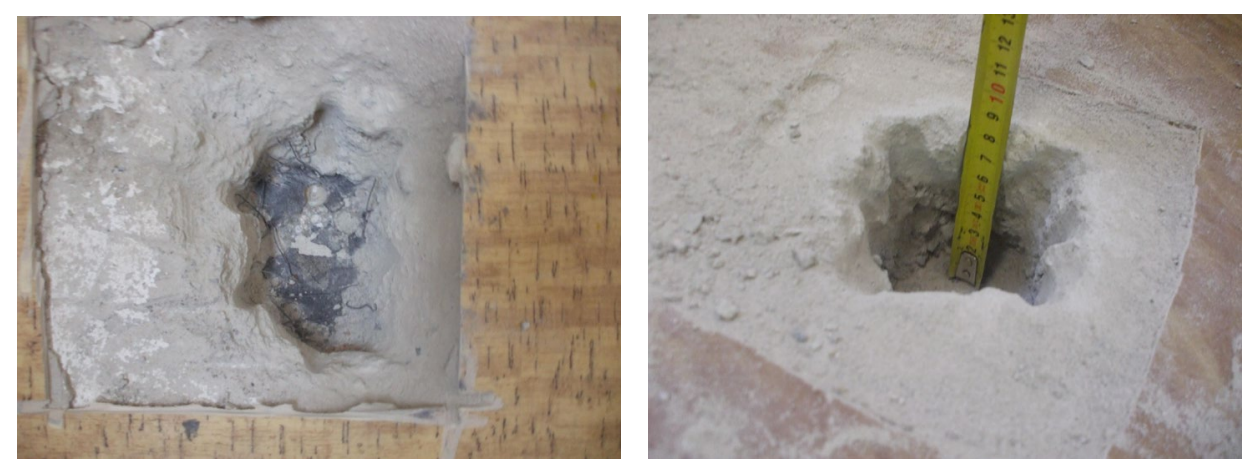

Figure 8: Probe to determine the thickness and composition of the floor on the ceiling panels

\section{Geological-engineering survey}

In terms of the geomorphological structure of Slovakia, the Košice basin, a sub-unit of the Košická plane is an area of geomorphological interest.

According to seismotectonic maps, Slovakia falls in the region affected by seismic shocks with intensity of up to 6 MSK degrees -64 .

According to the climatic areas, the studied area is classified as a warm area (T), which is characterized by the number MEAN 50 and more summer days per year (with a daily maximum air temperature $\geq 25{ }^{\circ} \mathrm{C}$ ). The area of interest is located in the district T5 (warm, slightly dry ward, with cold winter).

\subsection{Geological-engineering extruded cores}

Four cores were extruded from a depth of $8.0 \mathrm{~m}$ u.t.. During the drilling works extruded cores were documented. Laboratory work was carried out in order to determine the physicalmechanical properties of the soil necessary for the categorizing the soil and to determine soil workability, Tab. 5. 


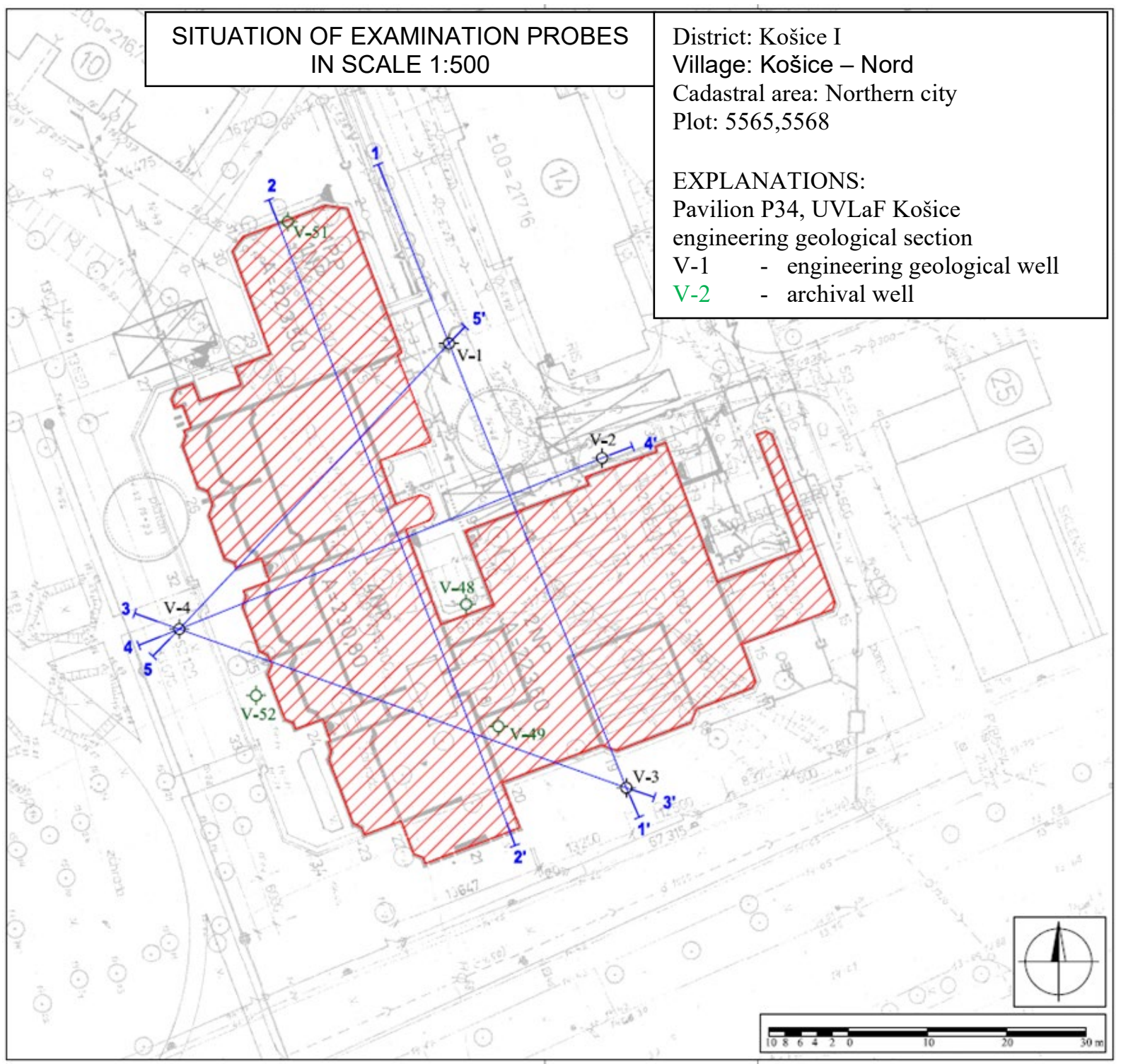

Figure 9: Situation of survey probes 

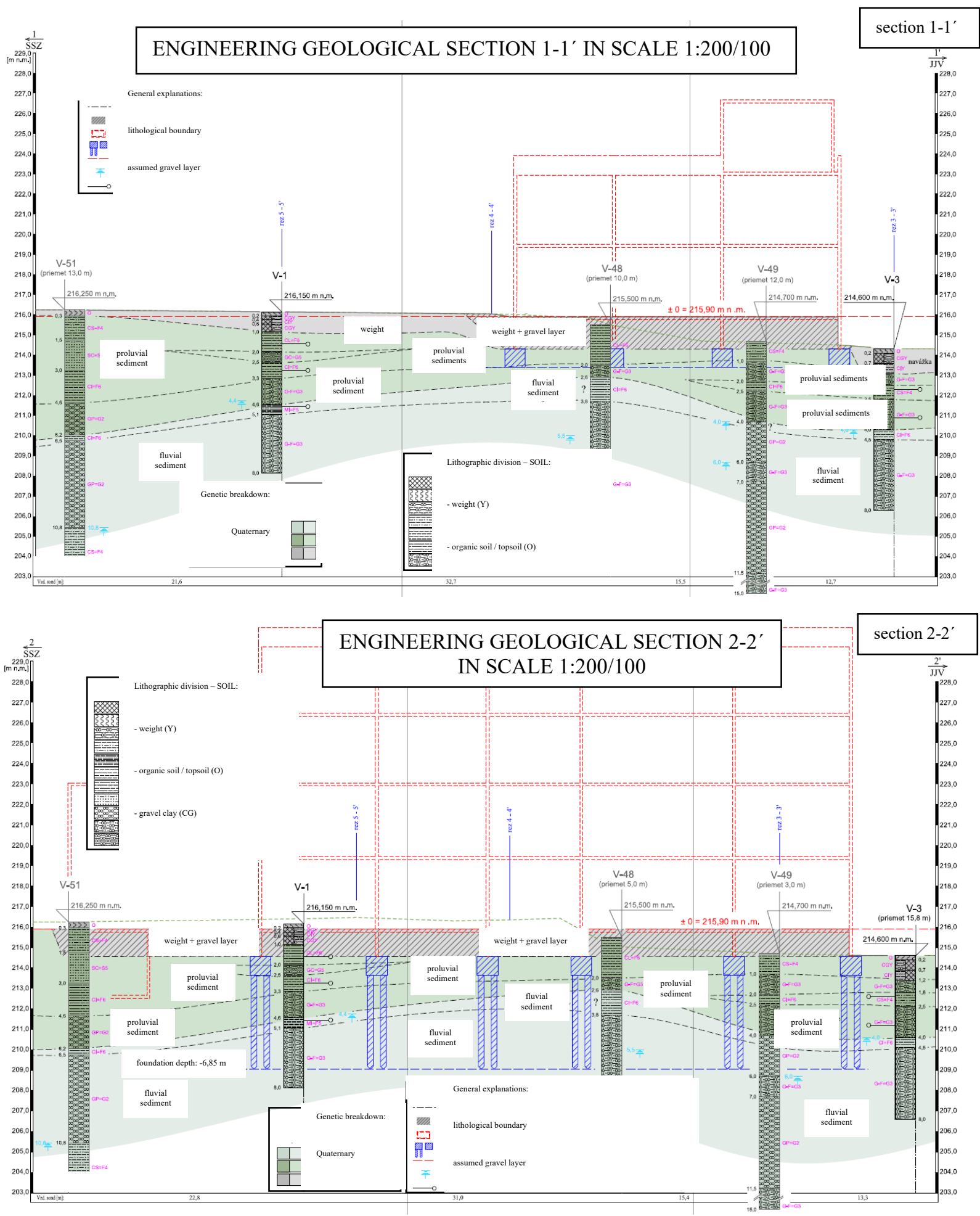


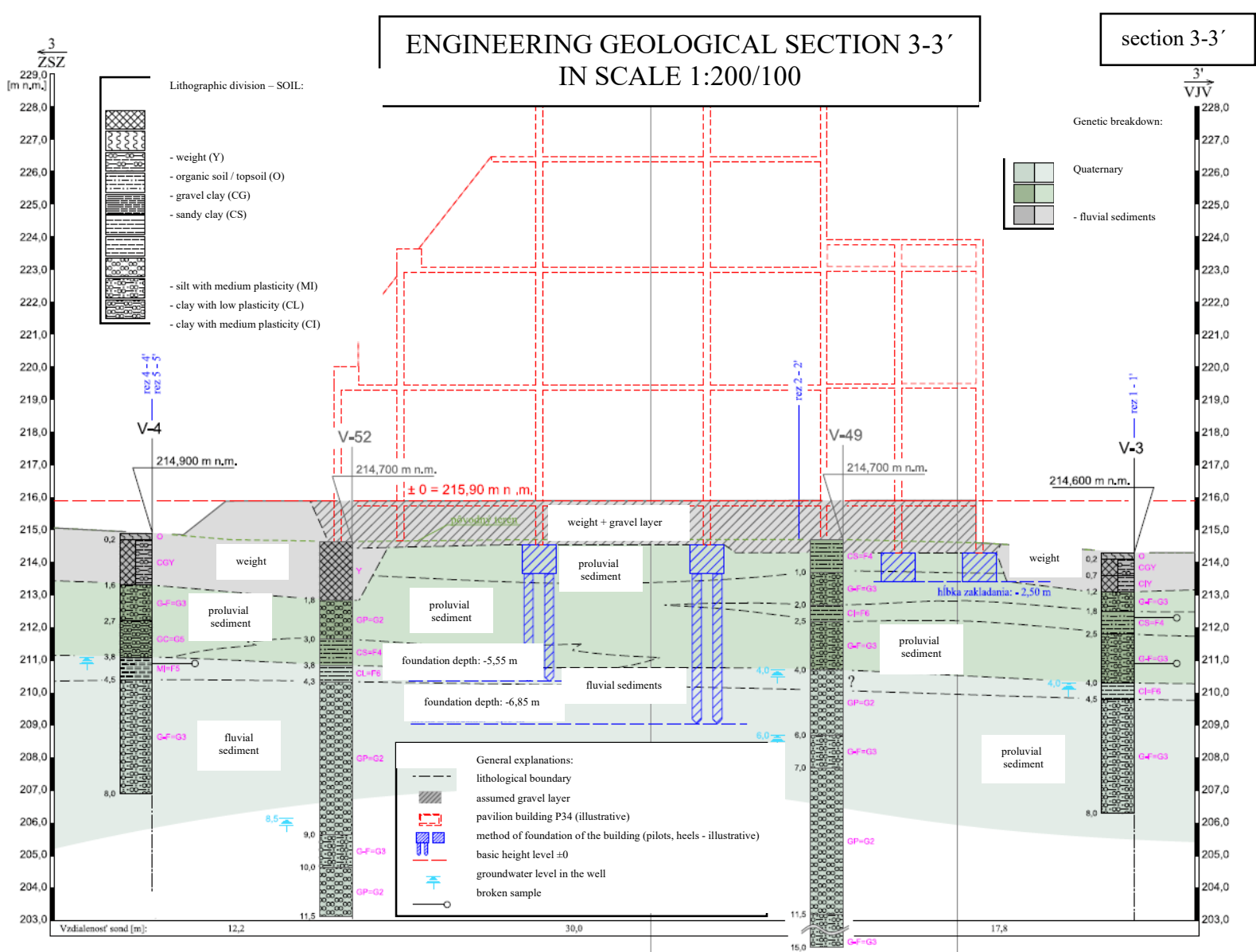

Figure 10: Geological-engineering sections

Table 5: Classification results of analyzed segments of earth samples

\begin{tabular}{|c|c|c|c|c|c|c|c|}
\hline Core & $\begin{array}{c}\text { Extrusion } \\
\text { depth } \\
(\mathrm{m})\end{array}$ & $\begin{array}{c}\text { Liquid } \\
\text { limit } \\
\mathrm{W}_{\mathrm{L}}(\%)\end{array}$ & $\begin{array}{c}\text { Plastic } \\
\text { Limit } \\
\mathrm{W}_{\mathrm{P}}(\%)\end{array}$ & $\begin{array}{c}\text { Plasticit } \\
\mathrm{y} \\
\mathrm{IP}_{\mathrm{P}}\end{array}$ & $\begin{array}{c}\text { Moisture } \\
\text { Content } \\
\mathrm{W}_{\mathrm{N}}(\%)\end{array}$ & $\begin{array}{c}\text { Consistency } \\
\mathrm{I}_{\mathrm{C}}\end{array}$ & $\begin{array}{c}\text { Grade acc. } \\
\text { STN } \\
721001 ~ \& \\
731001\end{array}$ \\
\hline V-1 & $1.6-1.7$ & 34.9 & 22.7 & 12.2 & 28.8 & 0.50 & CL, F6 \\
\hline V-1 & $2.9-3.0$ & 35.4 & 23.5 & 11.9 & 28.0 & 0.62 & CI, F6 \\
\hline V-1 & $4.7-4.8$ & 38.7 & 25.8 & 12.9 & 32.8 & 0.46 & MI, F5 \\
\hline V-2 & $5.4-5.5$ & 26.6 & 19.6 & 12.9 & 24.6 & 0.29 & CS, F4 \\
\hline V-2 & $6.4-6.5$ & - & - & - & - & - & G-F, G3 \\
\hline V-3 & $2.0-2.1$ & 35.0 & 21.7 & 13.3 & 22.2 & 0.96 & CS, F4 \\
\hline V-3 & $3.4-3.6$ & - & - & - & - & - & G-F, G3 \\
\hline V-4 & $4.0-4.1$ & 43.7 & 26.5 & 17.2 & 34.2 & 0.55 & MI, F5 \\
\hline
\end{tabular}

Completed drilling and laboratory test results clearly indicate the presence of cohesive soils at the top and bottom of the verified profile. At the time of the structure's design the soil had a solid and firm consistency. It is likely that over the life of the building changes in consistency 
occurred due to infiltration at the foundation base, and also to a change (decrease) of their strength-deformation characteristics.

Damage to structures around the perimeter of the structure indicates a lack of backfill compaction, respectively in areas with rainfall infiltration and the potential leaching of fine grain gravel layer below the building and subsequent settling evidenced by deformation on the surface.

Results of a detailed engineering survey are presented in [6].

\section{$6 \quad$ Ceiling panels check}

Structural analysis was realised using finite element based on software ANSYS. The precast ceiling panels were analysed in order to calculate internal forces and stresses:

- prestressed panel PZD 5/475,

- prestressed panel PPD 918/312.

The geometry was modelled in the software with all the structural parts, i.e. concrete, steel reinforcement, prestressing cables with prestressing force $100 \mathrm{kN}$. Material characteristics of the concrete was applied in accordance with the parameters found by experimental in-situ measurements. Computed response, such as displacements, deformations, stress were checked with technical standards.

\subsection{Precast prestressed panel PZD 5/475}

Following loadings acting on the panel was considered:

- self weight,

- weight of the floor $2 \mathrm{kN} / \mathrm{m}^{2}$,

- weight of the wall (height $3 \mathrm{~m}$ ) with windows $10 \mathrm{kN} / \mathrm{m}$,

- live load $3 \mathrm{kN} / \mathrm{m}^{2}$.

Max. stress in computed response was 4.35 MPa.

a)

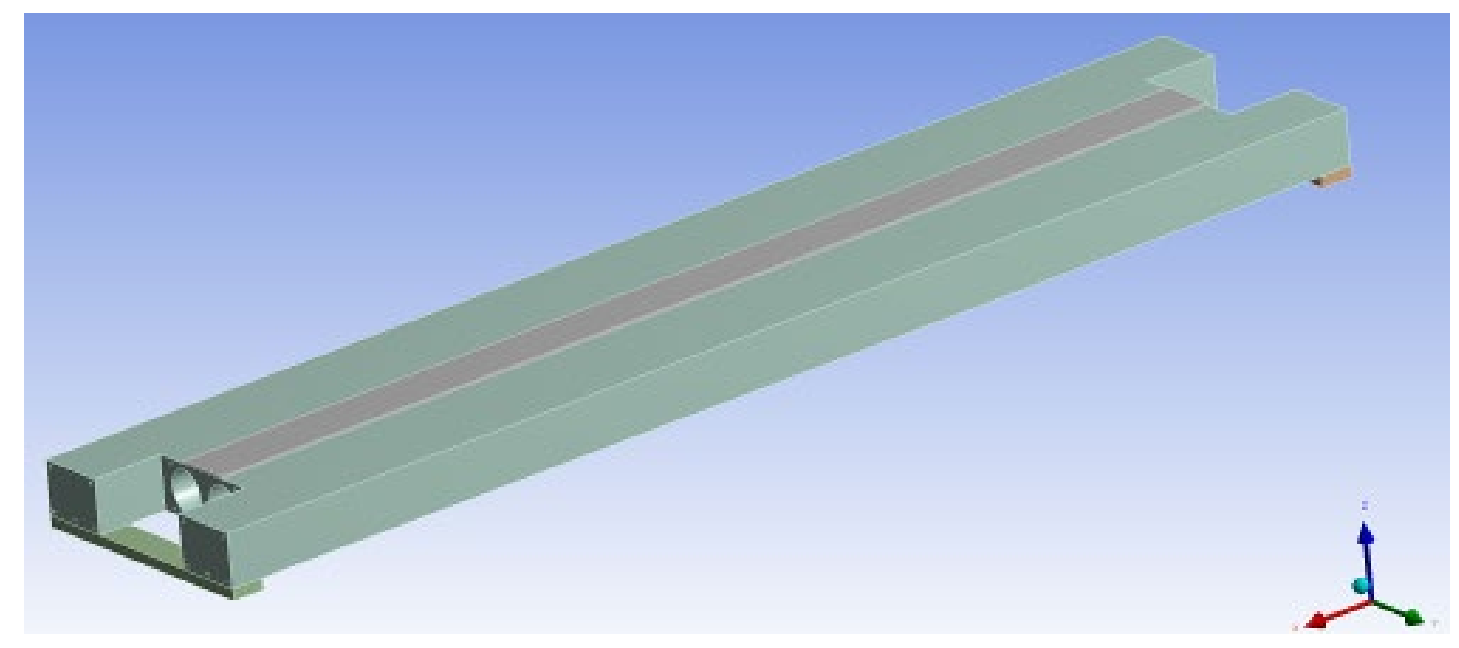


b)

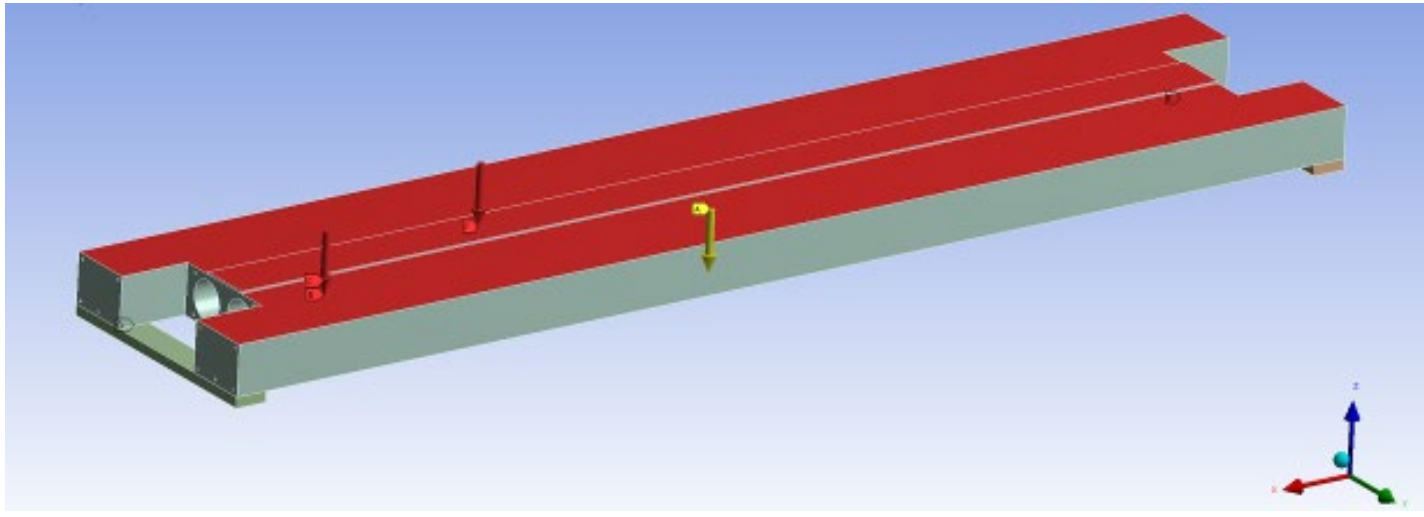

Figure 11: Geometry of the numerical model of panel PZD 5/475;

a) geometry of the panel

b) loadings acting of the panel

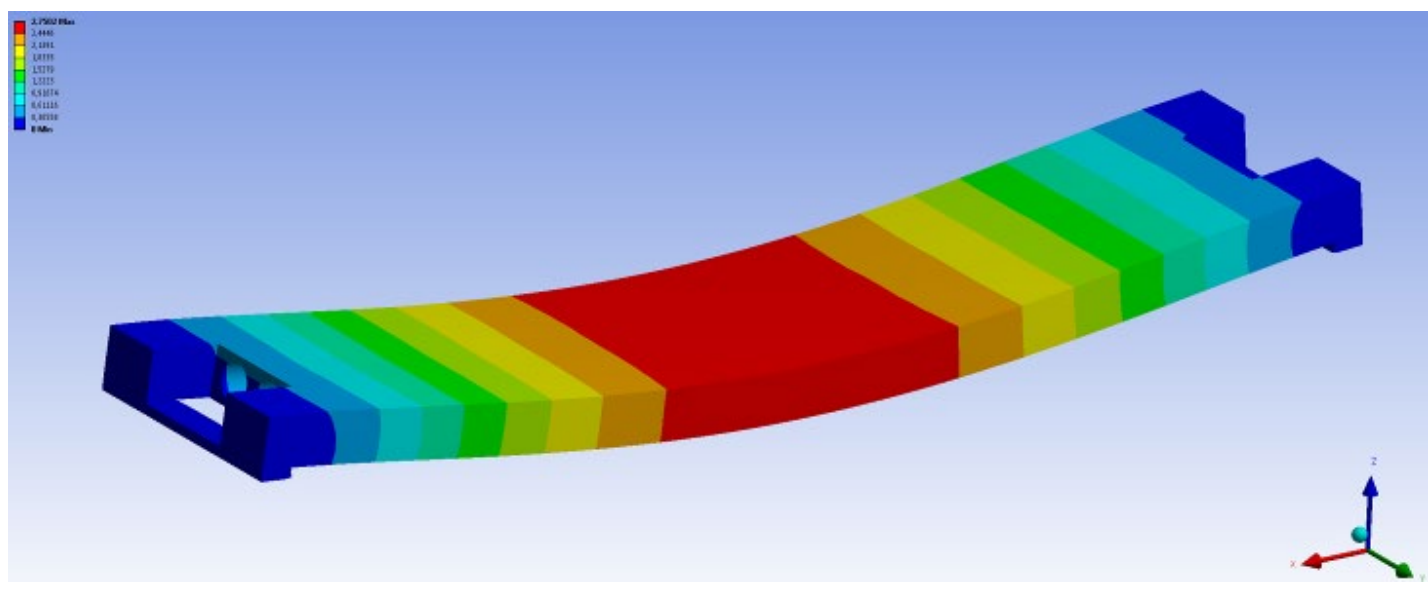

Figure 12: Response - displacements of the panel (max. $2.7 \mathrm{~mm})$

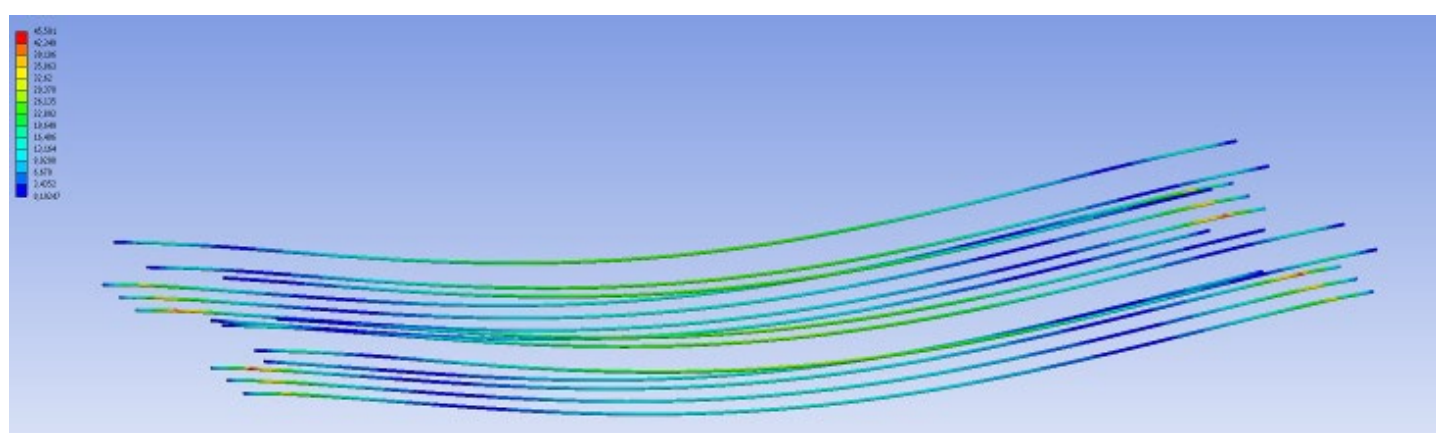

Figure 13: Response - stress in prestressing cables (max. 45.5 MPa) 


\subsection{Precast prestressed concrete panel PPD 918/312}

Following loadings acting on the panel was considered:

- self weight,

- weight of the floor $2 \mathrm{kN} / \mathrm{m}^{2}$,

- weight of the wall (height $6 \mathrm{~m}$ ) with windows $20 \mathrm{kN} / \mathrm{m}$,

- live load $3 \mathrm{kN} / \mathrm{m}^{2}$.

Max. stress in computed response under self weight and permanent loading was $8 \mathrm{MPa}$.

Max. stress in computed response under self weight and permanent loading and wall was 20 MPa.

Max. stress in computed response under self weight, permanent loading, wall and varying loading was $23 \mathrm{MPa}$.

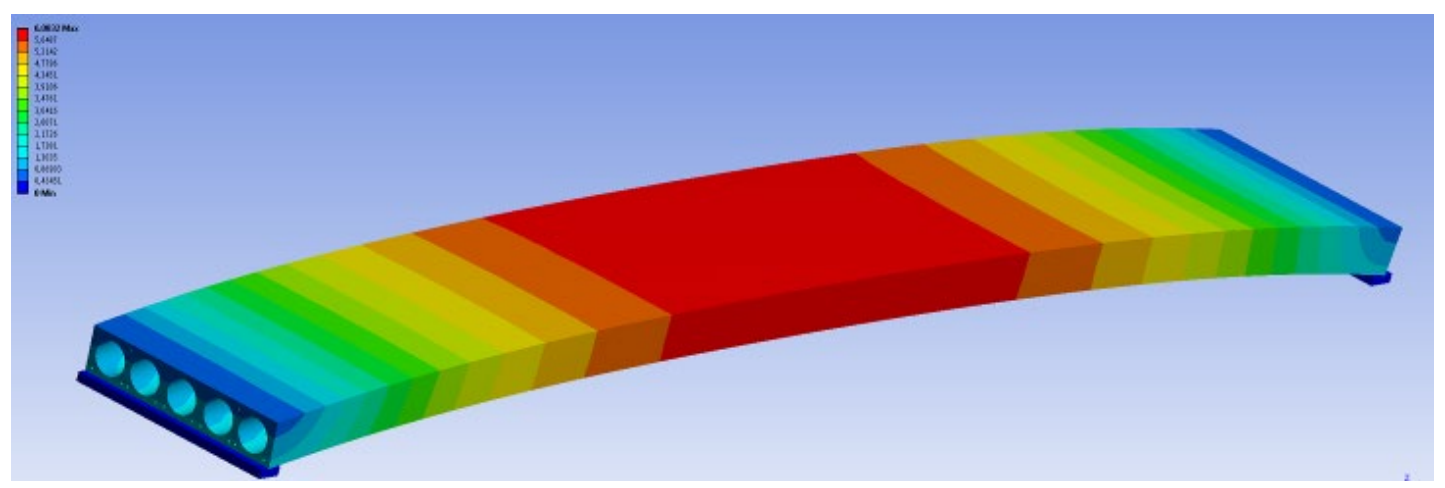

Figure 14: Response under self weight and permanent loading - displacements (max. $-6 \mathrm{~mm}$ )

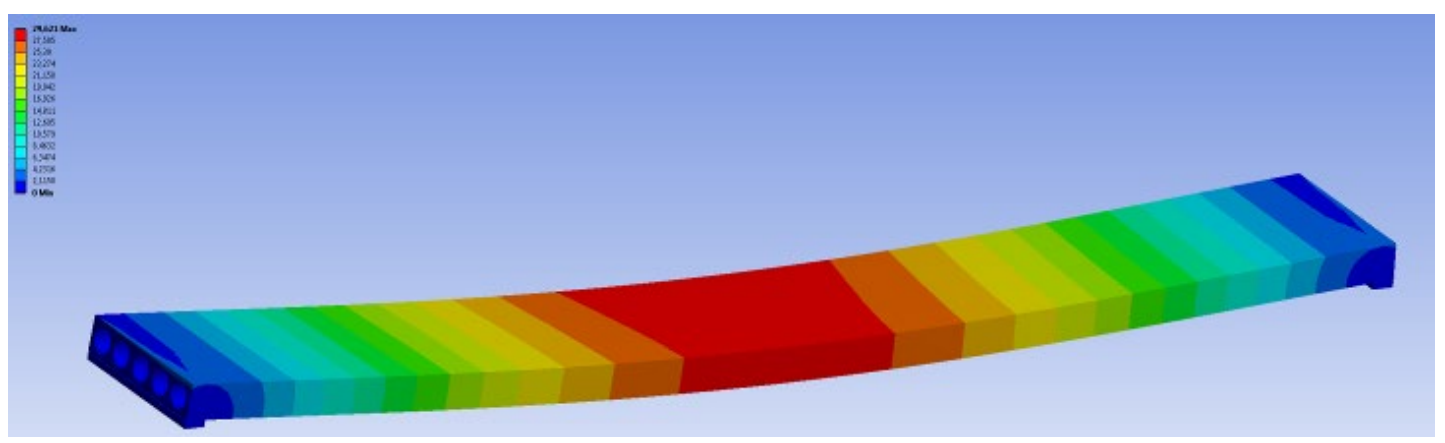

Figure 15: Response under self weight, permanent loading and wall - displacements (max. $29.6 \mathrm{~mm})$ 


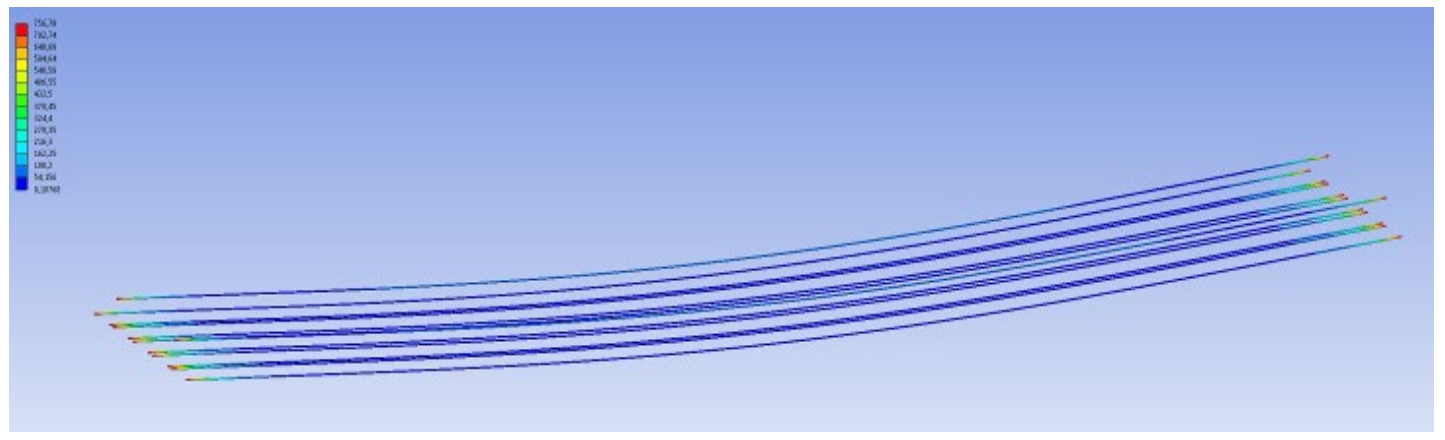

Figure 16: Response - stress in prestressing cables

$(\max .756 \mathrm{MPa})$

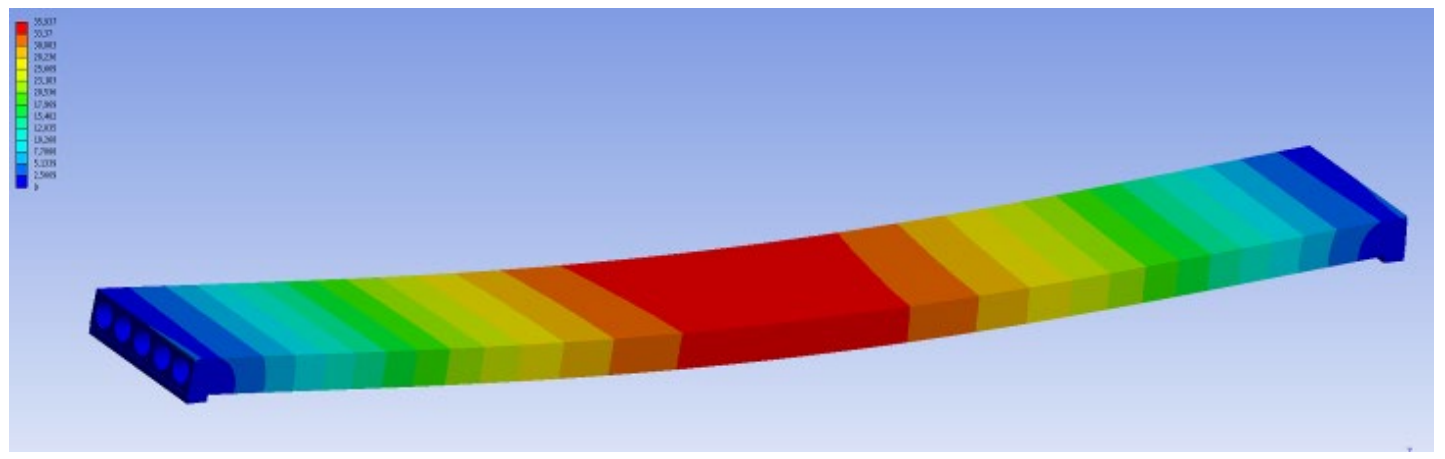

Figure 17: Response under self weight, permanent loading, wall and varying loading displacements (max. $35.9 \mathrm{~mm})$

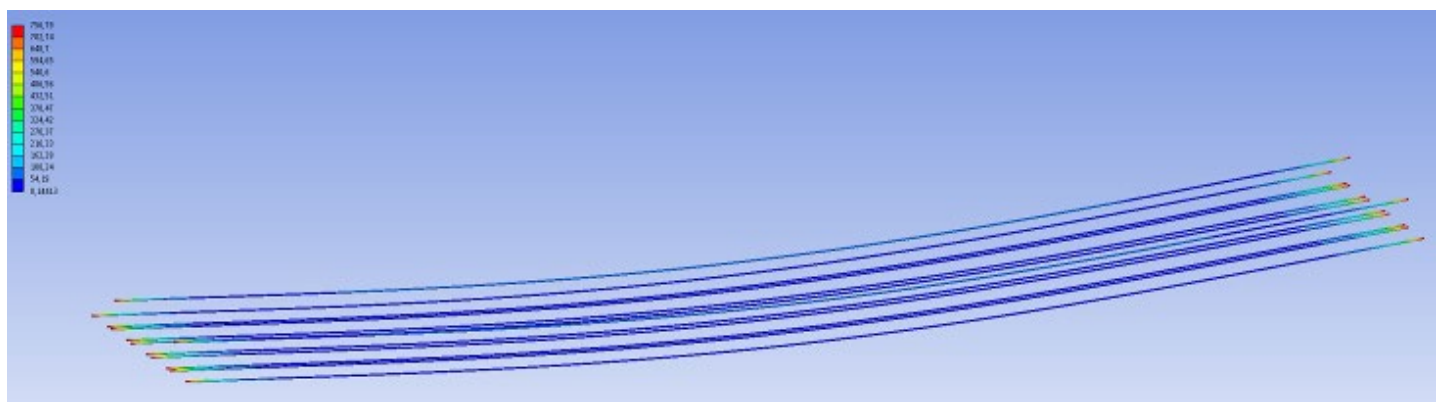

Figure 18: Response - stress in prestressing cables (max. $756 \mathrm{MPa}$ )

Measured difference between displacements of panel loaded with wall and without wall was $35 \mathrm{~mm}$.

\section{$7 \quad$ Structural analysis}

Global structural analysis of the precast concrete building was realised using finite element based software SCIA Engineer. Static response of the 2-storey part and 4-storey part of the building was calculated. The model consisted of 1D beam and 2D plate elements. Subsequently, internal forces and stress of structural elements were analysed, as well as the 
action on the foundations was calculated. The response of foundations, after taking into consideration in-situ measured geological profiles of the soil, was checked in accordance to normative standards.

Based on the results of the static analysis of the three-dimensional mathematical model, these conclusions were stated:

- for the 4-storey building (located in the middle of the building, the MSRP precast system type), the group of piles consisted of 2 piles (each of $430 \mathrm{~mm}$ diameter) with the pile head of dimensions $1600 \times 1600 \times 1100 \mathrm{~mm}$, these piles do not meet the requirements for the vertical resistance. Also the piles separately do not meet the requirements for vertical resistance.

- for the 2-storey building (located in the rear of the building, the MSRP precast system type), the precast footings of dimensions $1700 \times 1700 \times 1100 \mathrm{~mm}$ do not meet the requirements for the vertical resistance.
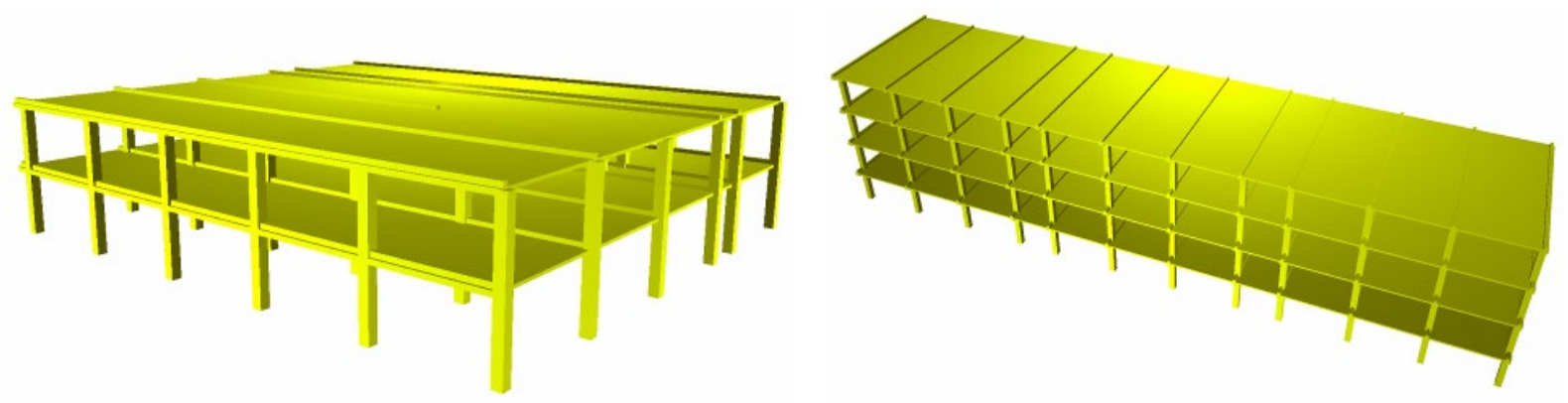

Figure 19: Rendered structural model 2- and 4-storey precast concrete skeleton MSRP type

\section{Conclusion}

Based on expert analysis, it is possible to evaluate that the diagnosed building structure has been subjected to differential settlement as a result of years of changes in the soil conditions in proximity to the foundations.

Due to differential settlements of foundations under the construction cracking has been observed in the partitions, which are located on first and second floor.

Remediation is required for the foundations (piles) to prevent further subsidence in the foundation and thus jeopardize the support of the reinforced concrete frame building.

Repairs to foundation structures must be implemented via injection after drilling the pile and floor. After implementation of foundation remediation work it is possible to then fill the cracks in the walls with expansive mortar.

In terms of functional and aesthetic requirements it is necessary to carry out remediation of deformed (wavy) floors as well.

It is necessary to carry out a revision of the vertical and horizontal pipes of plumbing beneath the floor structure that are located beneath the base of the building structure.

From the ceilings and walls locally damp areas from rainwater infiltration through the roof construction can clearly be seen, which causes degradation of the concrete bearing part of the 
structure. In terms of thermal-technical, operational and aesthetic requirements roof, gutter and downspout repairs are needed.

The vertical bracing of two stiffening walls must be added to increase horizontal stiffness. The precast concrete panel must be supported from the bottom side by adding steel truss substructures.

\section{Acknowledgements}

The paper is carried out within the project No. 1/0129/20, partially founded by the Science Grant Agency of the Ministry of Education of Slovak Republic and the Slovak Academy of Sciences. This work was partially supported by the Slovak Research and Development Agency under the contract No. APVV-15-0777.

\section{References}

[1] Structural engineering design plan (without civil engineering part and geotechnical part), Stavoprojekt Košice (1984).

[2] Structural expertise of current state of the building,

Technical University of Košice, Faculty of Civil Engineering (2016),

[3] STN EN 1992-1-1: Eurocode 3 (2015): Design of concrete structures - Part 1-1: General rules and rules for buildings, SÚTN.

[4] STN ISO 13822 (2012): General rules for design of structures. Assesment of existing structures. SÚTN.

[5] STN EN 731001 (2010): Geotechnical structures. Foundations of structures. SÚTN.

[6] Geotechnical expertise, UVLF of Košice, Pavilion P-34, TERRA - GEO, s. r. o., Košice (2016). 